\title{
STABLE ISOTOPE GEOCHEMISTRY OF SULFIDES FROM INTRUSION IN MONCHEGORSK, NORTHERN PART OF BALTIC SHIELD
}

\author{
MILOSZ A. HUBER ${ }^{1}$, STANISŁAW HALAS ${ }^{2}$, YURI N. NERADOVSKY ${ }^{3}$, TAMARA B. BAYANOVA ${ }^{3}$, \\ ARTEM W. MOKRUSHIN ${ }^{3}$ and LESIA LATA ${ }^{1}$ \\ ${ }^{I}$ Maria Curie-Skłodowsk University, Department of Geology and Lithosphere Protection, \\ 2 cd Kraśnicka St., 20-718 Lublin, Poland \\ ${ }^{2}$ Maria Curie-Skłodowska University, Mass Spectrometry Laboratory, Institute of Physics, Lublin, \\ 1 M. Curie-Sktodowska Sq., 20-031 Lublin, Poland \\ ${ }^{3}$ Geological Institute of the Kola Science Center, Russian Academy of Science, 14 Fersmana St. 184209 Apatity, Russia
}

Received 24 June 2015 Accepted 4 February 2016

\begin{abstract}
The sulfide minerals from old mafic intrusion rocks from the Kola Peninsula were analyzed on stable sulfur isotopes. These samples were already dated by the $\mathrm{Sm}-\mathrm{Nd}$ method. These sulfide samples were evaluated upon a geochemical composition by ICP-MS. The sulfide mineral samples were selected from the main ore-bearing rocks of the Monchetundra layered intrusion. The analyzed sulfides formed several generations of mineralization associated with primary and hydrothermal stage of formation of the deposits. Isotopic studies confirm a few consecutive stages of mineralization. These data were compared with the results of Sm-Nd dating of sulfide mineralization. The results of geochemical and geochronological studies indicate a complementarity in the context of determining the mineralization stages.
\end{abstract}

Keywords: geochemistry, geochronology, stable isotope analysis, sulfide minerals, Baltic Shield, Monchegorsk pluton.

\section{INTRODUCTION}

The Baltic Shield is a part of the East European Kraton (EEC), revealing to the north-east of St. Petersburg, appearing in the region of Karelia, Finland, Sweden and the Kola Peninsula, disappearing in the north-west at Caledonian massif of the Scandinavian Mountains, located in Norway. The rocks located within the Baltic Shield are divided into several specific blocks. They are: Kola and Belamorian, Karelian and Svekofenian and Scandinavian or Sveko-Norvegian Blocks.

Corresponding author: M. A. Huber e-mail: mhuber@poczta.umcs.lublin.pl
The oldest blocks in the Baltic Shield are Kola and Belamoryian. They are exposed mainly in the area of the Kola Peninsula and Karelia. In some locations these rocks reach the age of about $3.7 \mathrm{Ga}$. They have a mosaic structure composed of migmatised granites with numerous intrusions and series of greenschists belts of an age between 3 and 2.4 Ga (Mitrofanov, 2000; Bayanova, 2004; Bayanova et al., 2010; Pozhylienko et al., 2002). Layered intrusions are exposed in different locations of the crystalline Carton of the Baltic Shield, including the Kola Peninsula. These intrusions are predominantly basic and ultrabasic, composed of peridotites and gabbroides accompanied by a marked horizontality ore mineralization metals of $\mathrm{Cr}, \mathrm{Ni}, \mathrm{Fe}$, and elements from the Platinum Group Elements (PGE) according to Mokrushin et al. (2014). These intrusions constitute among others the Monchegorsk, Piechenga and Fedoro-Pana tundra massifs. 
The Monchegorsk Massif is located in the central part of the Kola peninsula, in a close vicinity of Khibina alkaline rocks. These intrusions constitute the extension of the Imandra-Warzuga belt which is located on the separating zone of the Kola and Belamoryan blocks. In Monchegorsk area there are numerous basic and ultrabasic intrusions that were relatively early investigated by the Russian geologists in the 1920s (Pozhylienko et al., 2002). They were dated using the U-Pb method to 2.446 Ga (Mokrushin et al., 2014). Besides gabbros, in the massif there are also peridotites and dunites bearing large mineralization containing chromium and nickel, iron, titanium and vanadium (Nerovich et al., 2009; Mokrushin et al., 2014; Serov and Ekhimova, 2009, Fig. 1). In the massif, platinum group elements (PGE) mineralization was encountered in the presence of sperrylite (Mokrushin et al., 2014).

In this study we consider different sulfide mineralization stages distinguished by petrological observations and by the sulfur isotope analysis of previously dated (Sm$\mathrm{Nd}$ ) sulfides.

\section{METHODS}

The samples of rocks were taken during a field trip in cooperation with Russian colleagues in the Monchegorsk Region. The samples of selected sulfide minerals were taken from Russian Academy of Science in Apatity (Russia). The sulfides were analyzed using an optical polarizing microscope Leica DM2500P and a scanning electron microscope Hitachi SU6600 with Energy Dispersive electron (EDS) which are installed in the Department of Geology and Lithosphere Protection at the Maria CurieSklodowska University (UMCS) in Lublin, Poland. The stable isotope analysis, $\delta^{34} \mathrm{~S}$, were made at the Institute of Physics at UMCS, Lublin, on a dual inlet and triple collector mass-spectrometer, using $\mathrm{SO}_{2}$ as the analyzed gas. The sulfide mineral specimens were quantitatively converted to $\mathrm{SO}_{2}$ in a vacuum line by their oxidation with analytical grade $\mathrm{CuO}$ reagent at temperatures between 800 and $900^{\circ} \mathrm{C}$. Along with the analyzed specimens, an aliquot of $20 \mathrm{mg}$ of the IAEA-S1 standard $\left(\mathrm{Ag}_{2} \mathrm{~S}\right)$ was converted to $\mathrm{SO}_{2}$ and analyzed using the mass spectrometer in order to normalize the obtained $\delta^{34} \mathrm{~S}$ values to the

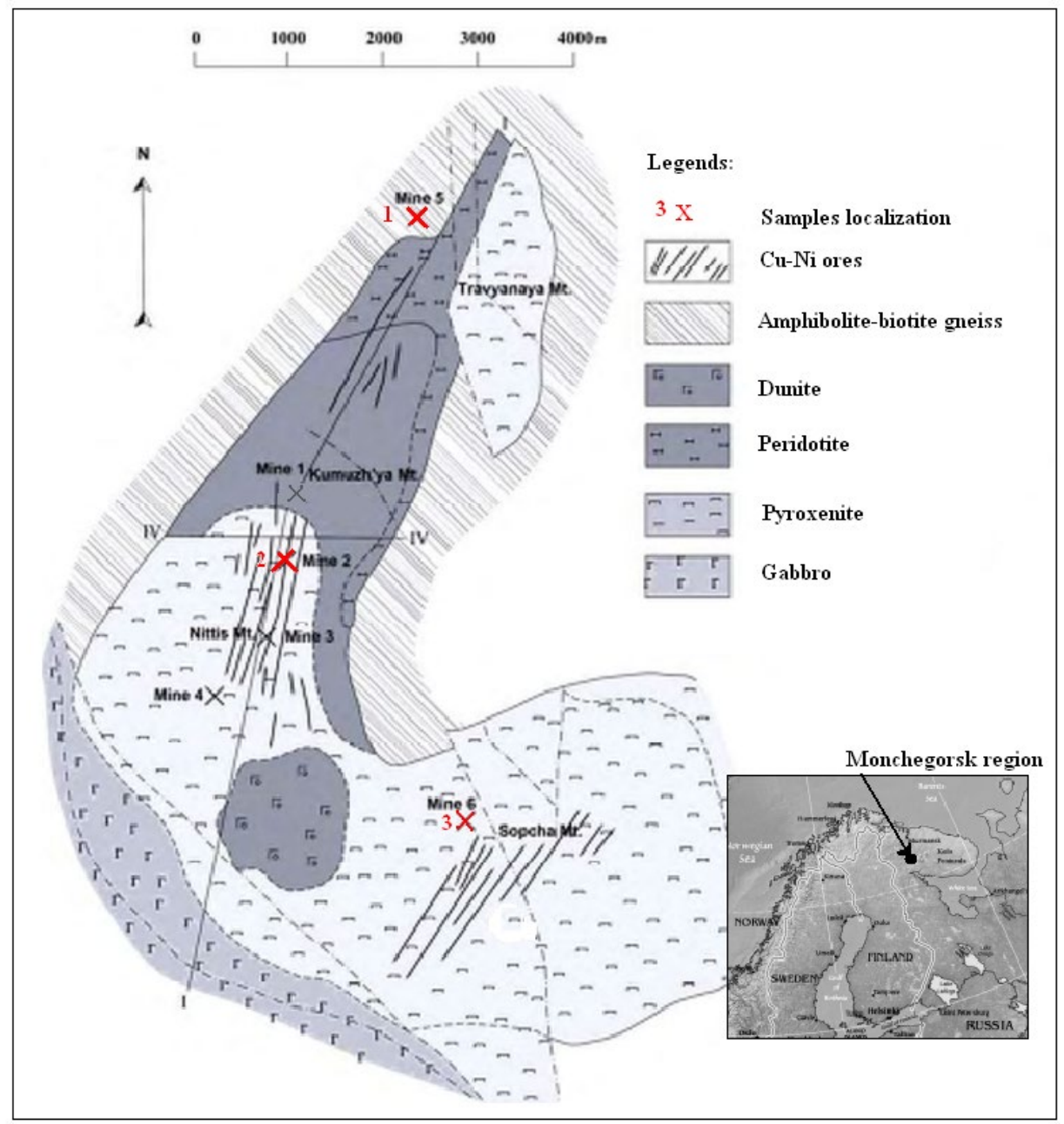

Fig. 1. Situated scetch of samples localization in Monchegorsk region (after Voytekhovsky and Neradovsky, 2008, changed by authors). 
Vienna Canyon Diablo Troilite (VCDT) scale. Selected samples were subjected to ICP-MS analysis (model ELAN DRC II, Perkin Elmer LSX-500, of CETAC) at the Soil Science and soil Protection Department at the UMCS. These analyses are necessary for the comparison of the microanalysis results in the studied sulfide minerals samples. They are also important to determinate the chemical composition and metallic additions in the analyzed sulfides.

\section{RESULTS}

The Monchegorsk Massif consists of basic and ultrabasic intrusions. These rocks are metamorphosed to a different degree. Relatively, the least metamorphosed are gabbroides occurring in the Monchegorsk region. A little further, on south-west there are rocks metamorphosed mainly in the amphibolite facies. Due to the nature of these intrusions, peridotites represent the most important type of rocks, accompanied by massive ore and the youngest breccias.
This peridotites have grey color with macroscopically visible pyroxenes and accompanying olivines with the addition of feldspars. It has a coarsely crystalline structure and a dense, disorderly texture. In the thin section there are visible clinopyroxenes, represented by augite and diopside, next to which there are amphiboles (common hornblende with a distinctive greenish pleochroism colors). These minerals are accompanied by chromite, olivines and sometimes basic plagioclase, mainly labradore. In addition to these minerals one can also encounter numerous ore minerals represented by titanomagnetite, pyrite and pentlandite (Fig. 2A, 2B).

Within these rocks they are associated massive sulfide ore deposits, mainly composed of pyrite and pentlandite, chalcopyrite and breccias containing all the above mentioned types of rocks. These breccias are composed of crushed rocks of peridotites which are cemented by quartz and sulfides. The microscopic observation indicates sulfides such as pyrite, chalcopyrite and secondary altered gabbroids by serpentinization and saussuritization processes (Fig. 3A, 3B).
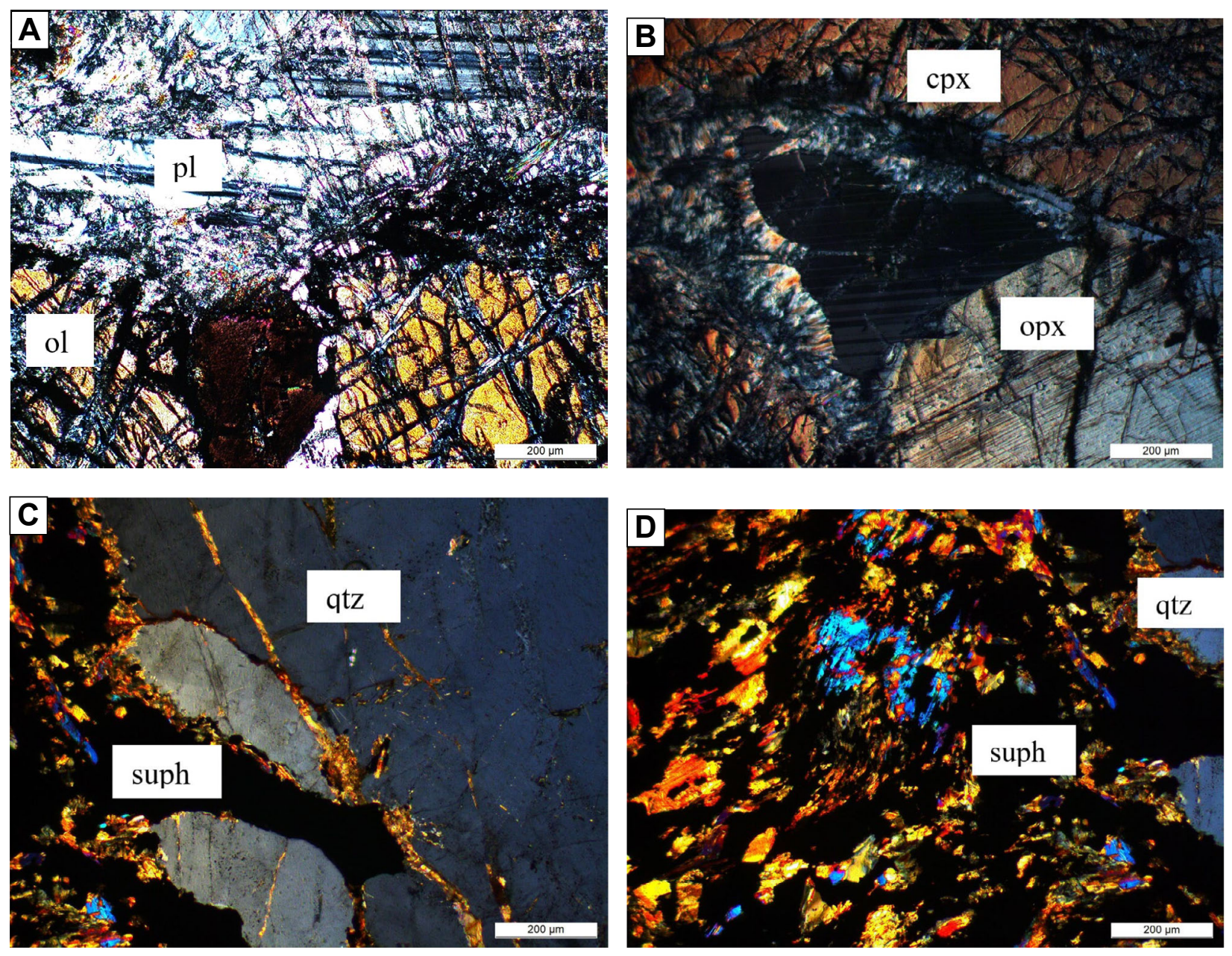

Fig. 2. Microscopic image of rock samples coming from the Monchegorsk Massif showing peridotites (sample 1, A, B) and quartz breccias (sample 3, C, D). Images obtained with an optical microscope, the polarizing light, crossed pollars ( $p l$ - plagioclases, ol - olivine, cpx - clinopyroxene, opx orthopyroxene, qtz - quartz, suph - sulfide). 

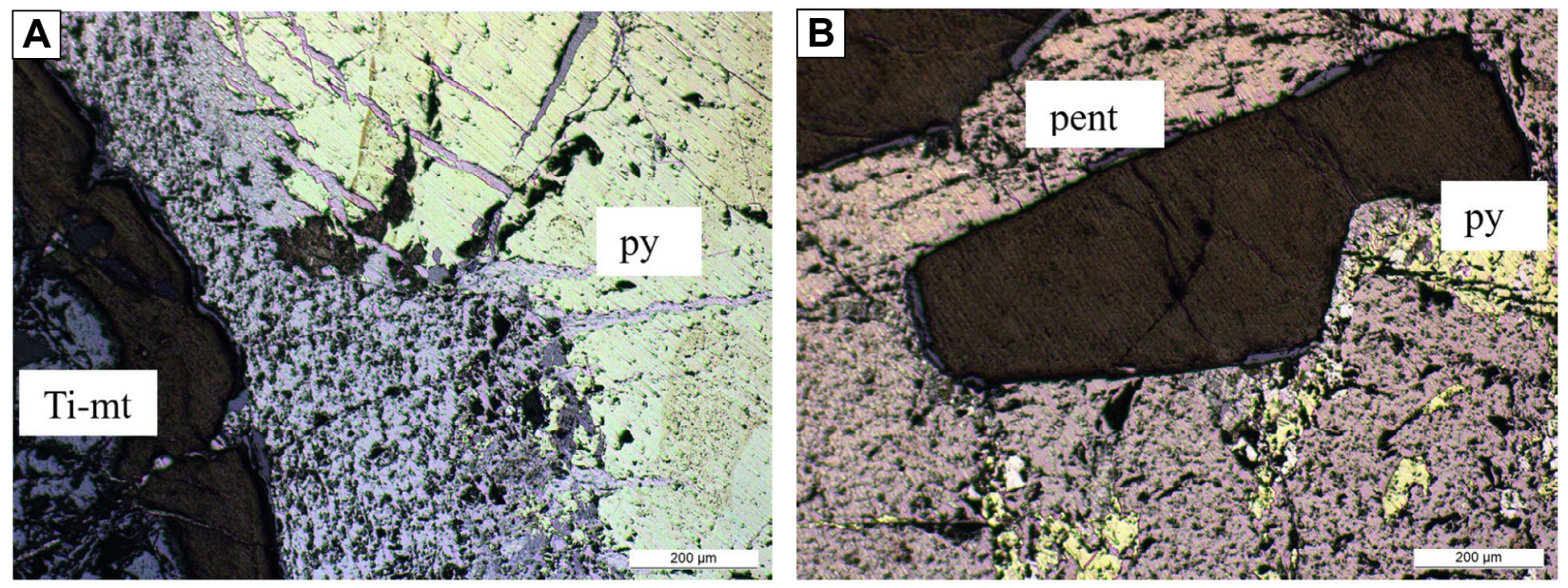

Fig. 3. Microphotographs of samples of massive sulfide mineralization from Monchegorsk (sample 2). The pyrite crystals with pentlandite and ilmenites with titanomagnetites (reflected light, py - pyrite, pent - pentlandite, Ti-mt - titan rich magnetite).

Studied sulfide minerals have shown that they are mainly crystals of pyrite and chalcopyrite accompanied grains of pentlandite and also magnetite, titanomagnetite and ilmenite. Especially in the massive ore samples of titanomagnetite, magnetite and ilmenite form enclaves, appearing in the form of aggregates in-between sulfides. In the close proximity of these minerals, pyrrohotite, bornite, cupropentlandite form characteristic lamellar adhesions and demix near the contact of iron minerals (visible in the microscopic image on Fig. 4).

Microscopic observation of ore minerals indicate the existence of several generations. The oldest, associated with primary magma mineralization is represented by the sulfides of nickel, accompanied by iron and titanium oxides. These minerals are visible both in peridotites as well as in the massive ores, where particularly oxides are surrounded by copper and iron sulfides, showing second- ary structures (Fig. 4). Another generation, the iron and copper sulfides is represented by pyrite, chalcopyrite sulphides. These minerals are visible both in the background peridotites as well as in massive sulfide ores and in the form of sulfide ores and breccias which form, together with pentlandite, the background of the rock. The last type of sulfide generation is pyrrhotite, which form the supporting structure of disintegrating chalcopyrite and pyrite, clearly visible in the microscopic image (Fig. 4).

The microprobe analyses of sulfides showed that the iron oxide is accompanied by small quantities of $\mathrm{V}_{2} \mathrm{O}_{5}$ and manganese oxides (Fig. 5) dominated by the coexistence of iron, copper and nickel.

The gabbronorites from the Pentlanditovaya Ushchelie deposits in the lowermost part of Monchegorsk pluton yielded $2489 \pm 49$ Ma $(\mathrm{Sm}-\mathrm{Nd})$ and $2501 \pm 5.6 \mathrm{Ma}(\mathrm{U}-\mathrm{Pb})$, respectively (Huber et al., 2014).
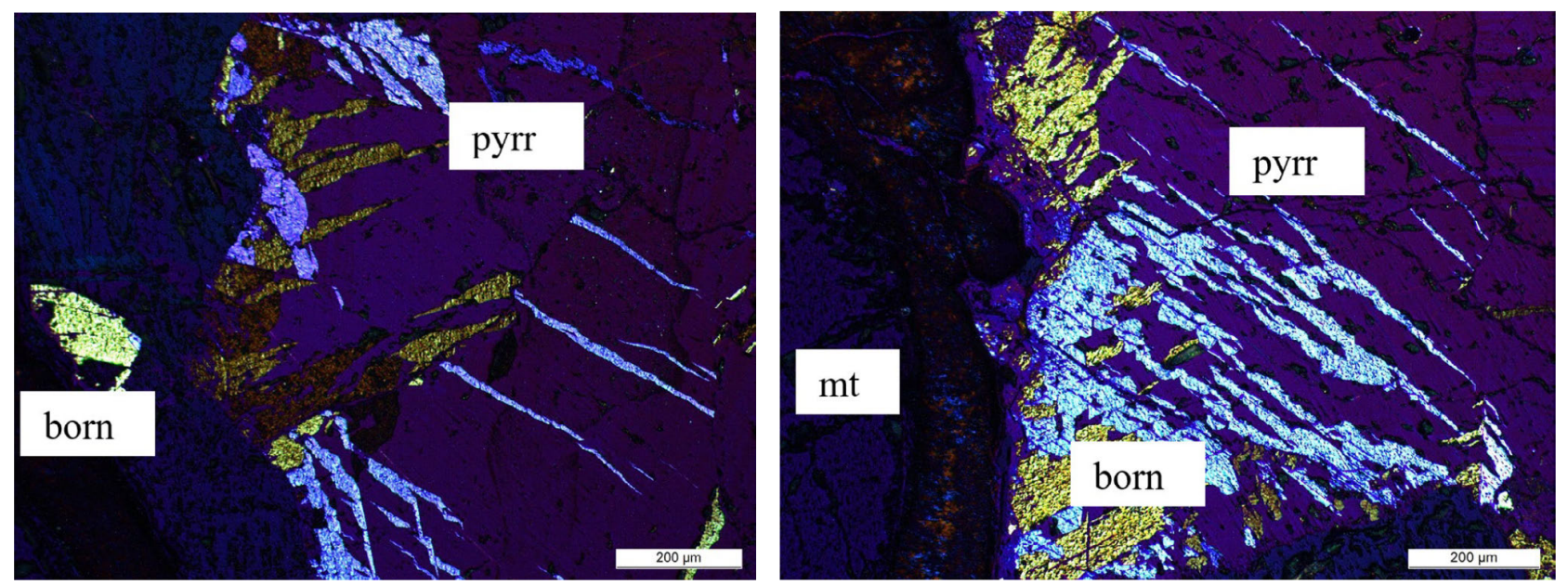

Fig. 4. Microphotograph of massive sulfide from Monchegorsk (sample 2, bornite, pyrrohotite, reflected light, crossed pollars, born - bornite, pyrr pyrrhotite, $m t$ - magnetite). 


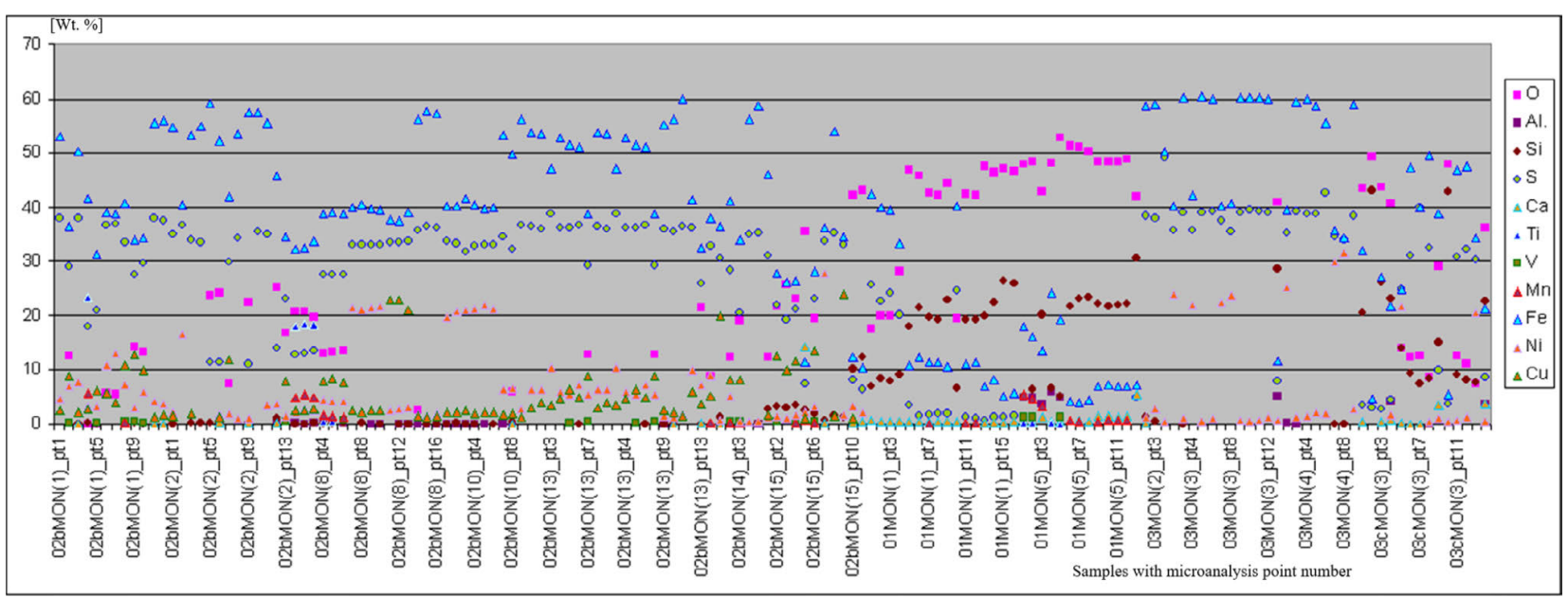

Fig. 5. Plots of the metals content (wt \%) in analyzed sulfide from Monchegorsk.

Results of stable sulfur isotope analysis of separated sulfide minerals of the three ore samples shows some variability (Table 1). Nickel sulfides have shown the most original isotopic composition of sulfur (oscillating around zero). Certain departures in $\delta^{34} \mathrm{~S}$ show pentlandites from the breccia, where there have sulfur isotope contamination by acts of secondary processes. The other analyzed sulphides (pyrite and chalcopyrite) show high variability. Their isotopic signature is specific to the primary magmatic formations and clearly indicates a fairly high contamination by supracrustal material, which caused strongly positive anomalies of these sulfides.

\section{DISCUSSION}

The examined three types of rocks from Monchegorsk contain several generations of sulfide minerals. The oldest of them are associated with magmatic rocks. Next generation was probably formed during metamorphism of these rocks, which has been identified by Serov et al. (Serov and Mitrofanov, 2005; Serov et al., 2007). Subsequently, the paragenesis of these minerals associated with hydrothermal processes, accompanied by the formation of massive ore and breccias in the fault zones. During these processes, there has been a corrosion and degradation of certain sulfides formed from the initial phase. These alterations have also affected the sulfur isotopic variation recorded in the analyzed samples of sulfide minerals. The oldest of them are clearly of the magmatic origin. The next generation of sulfides is associated with intrusion of alkaline rocks located in the massif. The last generation is associated with the migration of fluids in the metamorphism and hydrothermal processes that already existed much later, during the reconstruction of tectonic processes of the massif. Similar results were also observed in the isotopic studies of sulfides taken from drilling and surface sampling troctolites and gabbro and contact zones of the central massif Fiodoro-Pana Tundra. They showed
Table 1. The results of the $\delta{ }^{34} S$ for the Monchegorsk sulfide minerals samples.

\begin{tabular}{lc}
\hline Sample & $\boldsymbol{\delta}^{34} \mathbf{S}$ vCDT $(\%)$ \\
\hline 01 pyrite with admixtures & 5.74 \\
01 pentlandite & 0.92 \\
\hline 02 pyrite & 1.36 \\
02 chalkopyrite & 2.52 \\
02 chalkopyrite & 0.58 \\
02 pentlandite & 2.18 \\
\hline 03 pentlandite & 0.04 \\
03 pentlandite & 1.04 \\
03 pentlandite & 3.34 \\
03 pyrite & 1.64 \\
03 pyrite & 0.75 \\
\hline
\end{tabular}

* admixtures of bornite and pyrrohotite

serious evidence multi-sulfide and oxide mineralization stages in establishing the changes in the isotopic distribution of the alloy from which the crystallization was emerged (Huber et al., 2009).

These results closely correlate with the change in the distribution of sulfur isotopes previously encountered in northern Canada and Greenland by Hattori et al. (1983). They found in their study start a significant $\delta^{34} \mathrm{~S}$ variability of sulfides younger than $2.2 \mathrm{Ga}$. Prior to that date sulfides have highly uniform isotopic composition, similar to that of meteoritic sulfur. They interpreted their founding as due to the change of atmospheric oxygen pressure in Early Proterozoic time.

Inasmuch as the oldest sulfides are as old as $2.5 \mathrm{Ga}$, as mentioned above, therefore our data presented in Table 1 may be attributed to various sulfide generations which were formed in the span from 2.5 to $c a$. $2.0 \mathrm{Ga}$. The oldest of them have $\delta^{34} \mathrm{~S}$ close to zero, whilst those younger than $2.2 \mathrm{Ga}$ are significantly variable. 


\section{CONCLUSION}

The analyzed sulfide minerals from Monchegorsk massif rocks indicate high variability of isotopic composition resulting from the coexistence of several generations of sulfides. These generations proceeded over a long span of time, from 2.5 to $c a$. $2.0 \mathrm{Ga}$. The ore minerals form a disintegrating structure with the sulfur contaminated by fluids of different backgrounds. These processes lead to forming ingrown, which makes it difficult to separate and causes large dispersion of data from the same rock sample.

Generally, the results of analyzes demonstrate the following characteristics of geological phenomena: multiple ultrabasic magma injection in the cooling rock which contributes to a certain oscillation of sulfur isotopes of primary sulfide phases, multi-stage mineralization (magmatic, magmatic secondary, hydrothermal, epigenetic) which is associated with metamorphism of sulfide ores and numerous regional tectonic processes.

\section{REFERENCES}

Bayanova TB, 2004. Vozrast repernych geologicheskich kompleksom Kolskogo regiona $i$ dlitelnos't processov magmatisma.(Age of benchmark geological complexes of the Kola region and magmatism processes action). Sanki Petersburg, Nauka, 174. (In Russian)

Bayanova TB, Nerovich LI and Mitrofanov FP, 2010. Monchetundrov- skiy bazitovyi massiv Kolskogo regiona: novye geologicheskie i izotopio-vozrastnye dannye (Monchetundra basite massif of the Kola region: new geological and isotope-age data). Doklady Akademii Nauk 431(2): 216-222. (In Russian)

Hattori K, Krouse HR and Campbell FA, 1983. The start of sulfur oxidation in continental environments: about $2.2 \times 10^{9}$ years ago. Science 221: 549-551, DOI 10.1126/science.221.4610.549.

Huber M, Halas S and Piestrzyński A, 2009. Petrology of gabroides and isotope signature of sulfide mineralization from Fedorov-Pansky layered mafic intrusion, Kola Peninsula, Russia. Geochronometria 33: 19-22, DOI 10.2478/v10003-009-0004-6.

Huber M, Hałas S, Lata L, Mitrofanov FP, Neryadovski YN and Bayanova TB, 2014. Stable isotope results of sulfides from old mafic intrusions in the Kola Peninsula (N Russia). Journal of Biology and Earth Sciences 4(S1): 27-28.

Nerovich LI, Bayanova TB, Savchenko EE, 2009. New data on the geology, petrology, isotope geochemistry and PGE mineralization Monchetundra massif. Viestnik MGTU 12(3): 461-477. (In Russian).

Mitrofanov AF, 2000. Geological characteristics of Kola peninsula. Russian Academy of Science, Apatity, pp. 166

Mokrushin AV, Kudyrashov VM and Huber M, 2014. First Discovery of sperrylite in archean patchemvarek gabroanorthosite (Kola region, Russia), in 12th International Platinum Symposium, 11-14 August, Yekaterinburg, Russia, 307-308.

Pozhylienko WI, Gavrilienko BV, Zhirov DV and Zhabin SV, 2002 Geology of the ore regions in Murmańsk District, Apatity, 360.

Serov PA, Nitkina EA and Mitrofanov FP, 2007. Comparison of the data on the U-Pb and Sm-Nd isotopic dating of the early phase and ore-bearing rocks of platinum Fedorova-Pana layered massif. Doklady Akademii Nauk 415(5): 1-3. (In Russian)

Voytekhovsky $\mathrm{Yu}$ and Neradovsky $\mathrm{Yu}, 2008$. The $\mathrm{Cu}$-Ni-PGE and $\mathrm{Cr}$ deposits of the Monchegorsk area, the Kola Peninsula, Russia. 33 IGC excursion No 48, August 15 - 21, 2008 